\title{
The Effect of Organizational Culture and Good Corporate Governance Mechanism on Human Resource Disclosure
}

\author{
Nadya Natalia Rorong ${ }^{*}$, Lodovicus Lasdi ${ }^{2}$ \\ 1,2Accounting Department, Widya Mandala Catholic University \\ Jalan Dinoyo 42-44, Surabaya 60236, Indonesia \\ *Corresponding author; Email: 1*nadyanatalia26@gmail.com, 2lodovicus@ukwms.ac.id
}

\begin{abstract}
Human resource is an important and valuable asset to reach competitive advantage for every firms. In the banking and insurance firms, human resource have an important role that is irreplaceable in the operational process of the firms. Human resource disclosure is an activity to disclose information about recruitment process, benefits, training and development program for employee. Therefore, human resource disclosure may provide additional information for the management and all the stakeholders in the development process of decision making. Factors that may affect the human resource disclosure are organizational culture, institutional ownership, and independent commissioner. The objective of this study is to investigate the effect of organizational culture, institutional ownership, and independent commissioner to human resource disclosure. The research's object are banking and insurance companies that listed in Indonesian Stock Exchange in 2016-2018, there were 55 companies which have been selected by purposive sampling technique. Data were analysed by using multiple regression analysis. Based on the analysis, the results show that organizational culture has positive impact to human resource disclosure. Therefore, institutional ownership and independent commissioner does not affect the human resource disclosure.
\end{abstract}

Keywords: Organizational culture; institutional ownership; independent commissioner; human resource disclosure.

\section{INTRODUCTION}

The advancement of Science and technology has transformed the dynamics of business into a science-based business and technology. Changes in business dynamics are one of the phenomena that occur so that industries are ready to enter the era of Industrial Revolution 4.0. The 4.0 Industrial Revolution is a revolutionary era that emphasizes the role of machinery to replace human roles in conducting work quickly and effectively in order to achieve competitive excellence. The emergence of the 4.0 industrial revolution is a phenomenon that can be seen in two different sides namely as an opportunity to produce an increasingly sophisticated industry by combining automation technology and cyber technology but on the other hand, the 4.0 industrial revolution also raises risks and threats that human resources within the company will be replaced by engines.

The Company in conducting business activities using value added as a benchmark for the improvement of welfare that created from the management of the company's maximal and productive resources [4]. Human resources is one of the tangible resources of the company that is very important and valuable because human resources have intangible resources in the form of intellectual capital that can contribute in bringing a competitive advantage to the company [19]

The intellectual capital that exists in human resources in the form of ideas, innovations, processes, patterns, knowledge that is not visible as well as a network of collaborations and relationships in an organization. The intellectual capitaly is very important in every human resource for supporting and carrying out business activities of the company [20]. Intellectual capital is also a reflection of all potential and capability in human resources that will then provide a valued added for companies in the eyes of stakeholders. In addition to the existence of a very important intellectual capital in human resources, the role of the company's human resources is crucial in carrying out the operational functions of the company and managing the company's resources, planning, and implementing business strategy to achieve the objectives of the company. A crucial human resource role for companies makes the company realize the importance of reporting and disclosure of human resources.

Human resource disclosure reflects the importance of human resources that have an indispensable knowledge and expertise in both intellect- 
tual capital and human resources roles ranging from strategy drafting to corporate strategy that will impact the company image or image in the public eye [15]. Therefore, human resources are an asset of the company that is considered important as other assets. In practice, human resource disclosure is one type of disclosure that has not been applied much to developing countries [10]. In Indonesia, human resource disclosures do not stand as individual components in the annual report, however, human resource disclosure items can be found as part of the additional information disclosed in the company's annual report.

In providing additional transparent information in the company in the form of Human Resource Disclosure, it is needed support from several factors, namely the existence of good organizational culture by emphasizing aspects of human resources (people-oriented culture) in achieving the company goals or goals. In addition, other factors that also affect Human Resource Disclosure is the mechanism of Good Coorporate Governance (GCG). The existence of Good Coorporate Governance (GCG) mechanism shows the presence of good supervision or monitoring function in the company so that it will encourage management in providing transparent information related to the company's human resources through Human Resource Disclosure. Therefore, this research will use organizational culture and mechanism of Good Coorporate Governance (GCG) consisting of institutional ownership and independent Commissioner as the factors affecting Human Resource Disclosure.

Organizational culture is a corporate culture that is reflected in the values of trust (belief values) such as the statement of vision, mission, or goal that the company wants to achieve. Statements of values in the form of vision and mission and objectives of the company become a key element of the organizational institutional context and influence the action of accountability to stakeholders [3]. Companies that have a culture that emphasizes on human (people-oriented culture) or humanistic aspects that are reflected in the statement of vision, mission, or corporate objectives will strongly uphold fair behaviour for employees. Therefore, as a real manifestation of corporate values that focus on people-oriented culture, the company will conduct Human Resource Disclosure [3]. Research discussing the influence of organizational culture on Human Resource Disclosure has a positive impact on the research organizational culture on Human Resource Disclosure [3].

The mechanism of Good Coorporate Governance (GCG) is a form of management accounttability to stakeholders based on the principles of transparency, accountability, responsibility, independency, and fairness [13]. One of the proprietary structures in the GCG component is institutional ownership. Institutional ownership is the proportion of shares owned by the organization as an external party such as banking, government, investment, and other institutions [23]. With institutional ownership, the oversight function of the company will be more stringent. The company's management will observe the interests of the shareholders as the owner of the company in carrying out its responsibilities [17].

The existence of institutional ownership in the company will show the more parties own the company and they are more responsive to the company's business activities [1]. The higher institutional ownership in the company will be able to encourage management to be sensitive to the needs of information required by the stakeholders in making decisions. The company will provide important information especially related to human resource management through Human Resouce Disclosure to prove that the management has been carrying out the functions and roles entrusted by the company's investors. Research discussing the influence of institutional ownership of Human Resource Disclosure shows that institutional ownership has a positive effect on Human Resource Disclosure [10]. Other studies have shown different outcomes regarding the influence of institutional ownership of the Human Resource Disclosure [18]. The results of the study stated that institutional ownership had no effect on Human Resource Disclosure [10].

The implementation of GCG in the company is also supported by the existence of independent commissioners who are tasked to supervise management and have the authority to advise the board of directors [9]. The existence of independent Commissioners is very important to realize the supervisory system to prevent management opportunistic behavior and encourage management to answer the management of the company to the stakeholders [3]. Therefore, the greater the existence of independent Commissioners, the greater the influence given to encourage management to make a disclosure related to human resource management in Human Resource Disclosure. Research discussing the influence of independent commissioner on Human Resource Disclosure has been conducted and shows that independent commissioners are positively influential in Human Resource Disclosure [10]. Other studies have stated that independent Commissioners have no effect on Human Resource Disclosure.

This study was conducted to develop previous research on the influence of organizational culture, 
institutional ownership, and independent commissioners as the results demonstrated by previous researchers were still inconsistent. In this study, researchers added company size and profitability as control variables to make research results more optimal and consistent. This research used the research object which is the banking and insurance company listed on the Indonesia Stock Exchange (IDX) period 2016 to 2018. This is because human resources serve as the spearhead of operational in the banking company to bring an excellent service for customers. The role of human resources is also very important for insurance companies because human resources have the role to develop the quality of appropriate products and insurance services and able to answer the needs of customers from time to time. Thus, the role of human resources in banking and insurance companies is crucial to support Human Resource Disclosure as an important information and to ensure one form of accountability to the stakeholders.

Resource-based theory sees that a potential resource for a company to achieve a competitive edge is a unique resource, not being easily imitated by competitors, and valued at the company. In achieving a competitive advantage, the company must recognize the resources that are scarce and potentially to provide value added for the company where the resource is the intellectual capital that exists in the human self. All the resources in the company have their own values and benefits, but it will be important for the company to realize and then focus on managing those scarce resources to create a sustainable competing advantage [5].

Human resources are a crucial resource for management attention because management not only focuses on the production process of raw materials into finished goods but on the optimal management of human resources for the company's business processes [26]. Therefore, human resources are viewed as a valuable resource for the company due to the role of human being that can not be replaced by machines or sophisticated technology. The role of human resources is important because there is an intellectual capital in the human being that contributes to innovation, giving ideas and solutions to formulate, plan, and implement corporate strategy to achieve competitive advantage. The intellectual capital in human resources are very useful for manage the company relationship with customers, suppliers, and all the stakeholders [14]. Companies that want to achieve a competitive advantage and have realized the importance of human resources will provide information to stakeholders through Human Resource Disclosure that can be useful for decision making.

\section{Intellectual Capital}

Intellectual capital is an asset in the form of knowledge that exists in human beings and can provide a valued added for the company to achieve a competitive advantage [23]. Intellectual capital is a set of intangible assets that drives organizational performance and creates value and benefits for the company. Intellectual capital has gained the attention of the company as a valuable intangible asset in achieving competitive advantage, but the measurement and reporting of intellectual capital is still not regulated in the specific and accurate statement of Financial Accounting Standards. Intellectual capital into the three main elements that include human capital as knowledge or assets of know-how that contributes to innovation and provision of solutions for the company [21]. Human capital also reflects the ability of the company's human resources by using knowledge, skills, and competencies. The organizational capital (Structural Capital) is the company's internal ability to perform business routines where the capability is sourced from intellectual performance and business performance optimally by human resources within the company, and the customer capital (Relational Capital) is a harmonious relationship between the company and its business partners who are external parties such as suppliers, customers, creditors to achieve a good relationship and the authorities are satisfied with the services and facilities provided by the company [21].

\section{Human Resource Disclosure}

Human Resource Disclosure is human resource disclosure in the recruitment, training, enhancement and development of employees into the organization [3]. Human resources are important aspects that need to get attention from the management of the company and the stakeholders because human beings are an important resource in the creation of quality products and services for the customer. Then, human resources also have a hard to quantify value but provide important benefits for the company so that the value of a person is an important aspect of the importance of human resources [19]. Human Resource Disclosure will help stakeholders to know the importance of optimal management of human resources and will assist in the development and improvement of employee quality and solve various problems related to human resources.

Human Resource Disclosure emphasizes the efforts and costs incurred by the company to manage, improve and develop the quality of human resources. Every effort and expense 
incurred by the company is believed to be beneficial for human resources to keep its existence so that it is not extinct and not replaced by machinery. In addition, the company also realized that with the wise and appropriate management of human resources will produce benefits for the company in achieving a competitive advantage [2]. Human Resource Disclosure provides information that emphasizes on management of human resources in the company, providing optimum information about the cost and value of the company's human resources [7].

Human Resource Disclosure is a disclosure made by companies related to human resources where this disclosure consists of 16 items [10]. The Human Resource Disclosure items demonstrate various aspects of human resource management which include costs and facilities incurred by the company for the development and improvement of the quality of human resources. With the increasing number of Human Resource Disclosure items disclosed by the company in the annual report, the company has demonstrated human resource information is crucial to be given to the stakeholders as a decision making consideration material. Human Resource Disclosure emphasizes on the costs incurred by the company as a form of effort and human resources management to bring about a competitive advantage for the company.

\section{Organizational Culture}

Organizational culture is a system that reflects the perception and meaning of any member of the organization without exception where such perception and meaning will differ between one organization and another. Organizational culture can be interpreted as a pattern that reflects beliefs and symbols that can develops without time constraints that holds the organization together [12]. Organizational culture plays an important role in corporate activities because organizational culture is believed to be a pattern that has deep meaning and meaning for all personnel within the company. The organizational culture which is the company's values as well as the patterns that govern how to behave and think one is reflected in the vision, mission, and main objectives expressed by the company [3]. The company's vision, mission, and objectives will be in-depth the values of each company's personnel and will automatically regulate employee behaviour and actions. It is important and especially in the organizational culture that organization culture can control and shape human attitudes and behaviors involved in all forms of activity in the organization. The culture of the organization that lives in a company can be an important value and characteristic that encourages the establishment of a common agreement between each personnel and members involved in the organization. The orientation of the Organization's cultural existence is the birth of the agreement and the distribution together to achieve the interests of individuals and corporations [11].

\section{Institusional Ownership}

Institutional ownership is the ownership of the company's shares owned by external parties such as insurance companies, banks, investments and other institutions [23]. The function of the implementation of the ownership also has a role to reduce the agency conflict that occurs between the manager and shareholders [8]. With institutional investors acting to effectively supervise the decision making process, it is expected to improve the monitoring function more efficiently and effectively. With institutional ownership, the surveillance system of corporate management will increase. External parties with company shares will have the power to support or not support the management's actions or decisions [16].

Institutional oversight of the company's management includes decision making and monitoring management compliance with rules, standards, or legislation applicable so that all information provided by the company in the annual report reflects the actual state of the company. The real information that reflects the actual state of the company will be very helpful for all the stakeholders in order to make a decision [24]. There are some advantages from the existence of institutional ownership like the company will be able to analyze information using aspects from professionalism so there is no doubt in the reliability of information and the supervision of the company's management in carrying out operational activities will be carried out even tighter [25].

\section{Independent Commissioner}

Independent commissioner is an independent party and has no affiliation with the management or directors of the company, the principal shareholders, and the Board of Commissioners [27]. The existence of independent Commissioner is required by the company in conducting supervisory function to the company's directors with full authority over the management of the company. Indipendent commissioners should act independently in carrying out their functions and roles for the benefit of the company. The existence of independent commissioners in the company can create an objective environment and be concerned with fairness and equality and to align various 
interests including company interests and stakeholder interests in making decisions for the sustainability of the company's life on an ongoing basis [13]. Independent Commissioners are responsible for implementing Good Corporate Governance (GCG) as independent commissioners are required to be neutral or impartial in both the board's policies and for the benefit of the stakeholder. In addition, independent Commissioners should also pay attention and not abandon the interests of minority shareholders.

\section{The Influence of Organizational Culture on Human Resource Disclosure}

Organizational culture is evident in the statements of vision, mission, and objectives that the company wants to achieve. The company's vision, mission, and objectives will be in-depth values of every personnel in the company and become a cornerstone in all personnel activities especially in thinking, speech, and behave [3]. Companies that have a vision, mission, and objectives that contain the role and contribution of human resources, the company adheres to peopleoriented culture. Companies with people-oriented culture will focus on human resources in all the activities undertaken to achieve success rather than focusing on task-oriented culture. Companies that realize the importance of human resources in the company will provide trust for the stakeholders that the company does the management of human resources well too. The results showed that organizational culture had positive effect on Human Resource Disclosure [3]. The company that has a organizational culture with the orientation of people-oriented culture that is reflected in the statement of Vision, mission, and the purpose of the company will tend to provide human resources related information in the annual report through Human Resource Disclosure.

$\mathrm{H}_{1}$ : Organizational Culture has positive influence on Human Resource Disclosure.

\section{The Influence of Institutional Ownership on Human Resource Disclosure}

Institutional ownership is the company's share ownership by external parties such as insurance companies, banks, investments and other institutions [10]. With institutional ownership in a company, opportunistic behaviour undertaken by corporate management can be prevented. Institutional ownership can improve management performance because management will appeal to investors' wishes and seek the necessary information needed for investor decision making. The management will strive to provide information that is important to the company through a voluntary disclosure of Human Resource Disclosure to demonstrate that human resources as an important resource for the company are well managed and optimal. The results of research conducted by demonstrate that the indicational ownership has a positive effect on Human Resource Disclosure [10]. It shows that the higher institutional ownership in a company, the higher the Human Resource Disclosure is done by the management

$\mathrm{H}_{2}$ : Institutional ownership has a positive effect on Human Resource Disclosure.

\section{The Influence of Independent Commissioner on Human Resource Disclosure}

Independent Commissioner is a very necessary party by the company in conducting supervisory functions to the management that manages the company [3]. The Independent Commissioner is the party that will determine how well supervisory functions are undertaken to prevent the behavior of opportunistic management of the company. Independent Commissioner are neutral parties and are appropriately independent for having no relation and special relationship to the company. The existence of independent commissioner in the company becomes very important in determining the implementation of corporate governance has been running well and effectively or just the opposite. If its goes to the opposite, than the company will determine the corrective actions and evaluation to achieve the good corporate governance [22].

Independent Commissioner in performing its functions and roles will be very concerned with the interests of stakeholders as parties who have an interest with the company but limited in the management activities of the company. With the Independent commissioner in the company, it can encourage management to work for the interests of the stakeholders. Therefore, the Independent Commissioner will encourage management to perform a good corporate resource management function. Good corporate management function is the reflection of good corporate governance by ensuring that management using all available resources as a form of deligation of authority from the owner to the directors as the company's management [6].

The real form of proof of company will be to manage the company's resources well and optimally can be done through voluntary disclosure. The voluntary disclosure of Human Resource Disclosure can be used as a means to demonstrate that human resources have been managed well and optimally by the management of the company and can be informed as stakeholder decision making. The results of the research concludes that independent commissioners have a positive effect 
on Human Resource Disclosure [10]. This shows that the greater the existence of independent Commissioners, the greater will be the encouragement of management to perform Human Resource Disclosure.

$\mathrm{H}_{3}$ : Independent commissioners have a positive influence on Human Resource Disclosure.

\section{RESEARCH METHOD}

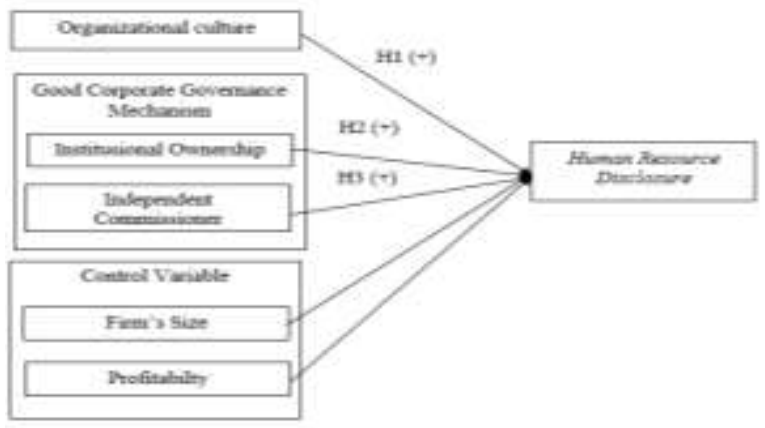

Figure 1. Research Model

The population in this research is the entire company listed on the Indonesia Stock Exchange (IDX) with the research samples which are insurance and banking companies registered at IDX in 2016-2018. This research uses the narrowing technique of purposive sampling method with criteria: first, banking and insurance companies listed consecutively in IDX period 2016-2018. Secondly, the banking and insurance company publishes an annual report on IDX period 20162018. Third, the banking and insurance company that publishes the annual report with the Rupiah currency unit in IDX period 2016-2018. Based on predefined criteria, of the number of banking and insurance companies registered in the IDX period 2016-2018 as many as 60 companies, there are 55 companies that can be a sample of research with the narrowing criteria of 1) There are 5 banking and insurance companies that are not listed and publish annual reports successively in IDX period 2016-2018, 2.2016-2018.

Table 1. Sampling Result

\begin{tabular}{|c|c|}
\hline & Total \\
\hline $\begin{array}{l}\text { The number of banking and insurance coupanies listed on } \\
\text { the Indonesta Stock Exchange during 2016-2018 }\end{array}$ & 60 \\
\hline $\begin{array}{l}\text { The number of unegistered banking and insurance } \\
\text { companies and issuing successive annual repoits on the } \\
\text { Indonesia Stock Exchange in 2016-2018 }\end{array}$ & (5) \\
\hline $\begin{array}{l}\text { The number of unregistered banking and insmrance } \\
\text { companies problished consecutive annual reports on the } \\
\text { lndonesia Stock Exchange in 2016-2018 }\end{array}$ & (0) \\
\hline $\begin{array}{l}\text { The mumber of banking and insurance compunies that meet } \\
\text { the sample criteria }\end{array}$ & .66 \\
\hline The number of resestch periods & 3 \\
\hline The number of final samples of research & 165 \\
\hline
\end{tabular}

\section{RESULTS AND DISCUSSION}

Measurement of Human Resource Disclosure in this study refers to previous research where there are 16 disclosure items [10]. Measurement of Human Resource Disclosure is Human Resource Disclosure item expressed by a company compared with the number of items of Human Resource Disclosure (16 items) measurement organizational culture in this study refers to previous research using dummy variable [3]. If the company has a statement of vision, mission, and the purpose of the company that emphasizes the role of human resources (people-oriented culture), it will be given a value of (1), and if not then will be given a value of (0). The measurement of institutional ownership is done by comparing the proportion of shares owned by the institution to the total outstanding shares [23]. The measurement of independent commissionners is conducted by comparing the number of independent commissioners to the number of Commissioners within the company. The study uses control variables namely Enterprise Size (SIZE) and profitability (ROA) This research has a purpose to test $\mathrm{H} 1, \mathrm{H} 2$, and $\mathrm{H} 3$. Hypotheses on this research are demonstrated through the research equation

$$
\begin{aligned}
H R D= & \alpha+\text { B1CLTR }+ \text { B2KI }+ \text { B3IND+ B4ROA }+ \\
& \text { B5SIZE }+\mathrm{e}
\end{aligned}
$$

Dimana:

$$
\begin{aligned}
& H R D=\text { Human Resource Disclosure } \\
& \text { CLTR }=\text { Organizational Culture } \\
& \mathrm{KI}=\text { Institusional Ownership } \\
& \text { IND = Independent Commissioner } \\
& \text { ROA = Profitability } \\
& \text { SIZE = Firm's Size } \\
& \mathrm{a}=\text { Constanta } \\
& \text { B = Regression Coeficient } \\
& \text { e }=\text { Error }
\end{aligned}
$$

In the results of a descriptive statistic (test Frekruensi), Organization Culture variable (CLTR) is converted using a dummy variable that is to provide a value of 1 to the company that has a statement of vision, mission, and the purpose of the company that emphasizes the role of human resources (people-oriented The descriptive statistical result (frequency test) shows that in CLTR variable there are 119 companies from 165 sample companies who have vision and mission to prioritize human resource role (people-oriented culture) with percentage of $72.1 \%$. While the company does not have a vision and mission prioritize human resources role of 46 companies with a percentage of $27.9 \%$ 
Table 2. Descriptive Statictic - Frequency Test

\begin{tabular}{cccc}
\hline Variable & Dummy & Frequency & Percentage \\
\hline \multirow{2}{*}{ CLTR } & 0 & 46 & 27,9 \\
& 1 & 119 & 72,1 \\
\hline
\end{tabular}

In the descriptive statistical results where the institutional ownership variables (KI) are proscribed by comparing the proportion of shares owned by the institution to the total of outstanding shares. The KI variable has a minimum value of 0.000 because there is a company that has no institutional ownership in the years 2016 and 2017, while the maximum value of the KI variable is 1.000. The average value of the $\mathrm{KI}$ variables amounted to 0.747 indicating that the average institutional ownership of banks and insurance companies registered in the IDX period 2016-2018 is large enough to $74.7 \%$. It shows that the share ownership of the banking and insurance companies registered in the IDX period of 2016-2018 is majority owned by the institution compared to individuals. Meanwhile, the KI variable has a standard deviation value of 0.261 which indicates that the KI variable has a low data diversity level.

The Independent commissioner (IND) variable is proscribed by comparing the number of independent Commissioners with the number of Commissioners within the company. The IND variable has a minimum value of 0.333 and the maximum value of the IND variable is 1.000 . The average value of the variable IND is 0.569 indicating that the average independent commissioner in the company and insurance period of 2016-2018 is reaching $56.9 \%$. It shows that the average number of independent commissioners in the bank and insurance company is flat in the IDX period 20162018 above $50 \%$ of the total Commissioner. Meanwhile, the IND variable has a standard deviation of 0.119 which indicates that the IND variable has a low data diversity level.

The company size variable (SIZE) is the control variable used in this study. The SIZE variable is proscribed with logarithms of total assets owned by the company and reported in the company's financial statements. The SIZE variable has a minimum value of 23.154 and a maximum value of 34.749 which is the value of Bank Rakyat Indonesia TBK (BBRI) in 2017. The average value of the variable SIZE is 30.200 which indicates that the average banking and insurance companies listed on the IDX period 2016-2018 have a large size. In that scenario, the SIZE variable has a standard deviation of 2.343 which indicates that the SIZE variable has a high level of data diversity.
The profitability variables measured using Return on assets (ROA) are the control variables used in this study. The profitability (ROA) variable is proscribed by comparing net profit after tax with the total assets of Ocompany reported in the company's financial statements. The ROA variable has a minimum value of- 0.117 and a maximum value of 0.232 . The average value of ROA variables amounted to 0.185 which shows that the banking and insurance companies listed on the IDX period 2016-2018 have an average profitability of $18.5 \%$. Meanwhile, the ROA variable has a standard deviation of 0.035 which indicates that the ROA variable has a low level of data diversity. The Human Resource Disclosure (HRD) variable is proscribed by comparing the number of HRD items disclosed by the company with the overall number of HRD items on the company's annual report. The minimum value of the HRD variable is 0.375 and the maximum value of the HRD variable is 0.750 . The average value of $\mathrm{HRD}$ variables in banking companies and 2016-2018 insurance period is 0.541 . This indicates that the banking and insurance companies of 2016-2018 period are conducting a high enough Human Resource Disclosure of up to $54.1 \%$. Meanwhile, the standard deviation of 0.077 indicates that the HRD variable has a low level of data diversity.

Table 3. Descriptive Statictic Results

\begin{tabular}{lccccc}
\hline Variable & $\mathbf{N}$ & Min. & Max. & Average & $\begin{array}{c}\text { Standard } \\
\text { Deviation }\end{array}$ \\
\hline KI & 165 & 0,000 & 1,000 & 0,747 & 0,261 \\
IND & 165 & 0,333 & 1,000 & 0,569 & 0,119 \\
SIZE & 165 & 23,154 & 34.749 & 30,200 & 2,343 \\
ROA & 165 & $(0,117)$ & 0,232 & 0,186 & 0,035 \\
HRD & 165 & 0,375 & 0,750 & 0,641 & 0,077 \\
\hline
\end{tabular}

\section{Hypothesis Testing}

The results showed that organizational Culture (CLTR) had a coefficient value indicating the positive direction (0.031) with a significance value of 0.004 . As such, Organizational culture has positive effect on Human Resource Disclosure. This suggests that the first hypothesis (H1) is accepted. Institutional ownership (KI) has a coefficient value indicating a negative value (-0.005) with a significance value of 0.800 . As such, institutional ownership has no effect on Human Resource Disclosure. This indicates that the second hypothesis (H2) is rejected. Independent commissioner (IND) has a coefficient value indicating a positive value (0.036) and a significance value of 0.275 . As such, independent commissioners have no effect on Human Resource Disclosure. This indicates that the third hypothesis (H3) was rejected. The control 
variables in this study are company size (SIZE) and profitability (ROA). The results showed that the company size had a coefficient value indicating a positive direction (0.022) with a significance value of 0.000 . Thus, the size of the company positively affects Human Resource Disclosure. Profitability (ROA) has a coefficient value that indicates a positive direction (0.008) with a significance value of 1.200. Thus, profitability has no effect on Human Resource Disclosure.

Table 4. Hypothesis Results

\begin{tabular}{ccccc}
\hline Variable & $\boldsymbol{\beta}$ & $\begin{array}{c}\text { Std. } \\
\text { Error }\end{array}$ & $\mathbf{t}$ & sig \\
\hline (Constant) & $(0,153)$ & 0,070 & $(2191)$ & 0,030 \\
CLTR & 0,031 & 0,011 & 2,889 & 0,004 \\
KI & $(0,005)$ & 0,020 & $(0,254)$ & 0,800 \\
IND & 0,036 & 0,033 & 1,095 & 0,275 \\
SIZE & 0,022 & 0,002 & 9,556 & 0,000 \\
ROA & 0,008 & 0,007 & 1,200 & 0,232 \\
\hline
\end{tabular}

The results of this study confirmed that organizational culture has positive effect on Human Resource Disclosure [3]. Companies that have a vision, mission, and objectives that contain the role and contribution of human resources, the company adheres to people-oriented culture. Companies with people-oriented culture will focus on human resources in all activities that are done to achieve success and not only focus on task and responsibility to be done (task-oriented culture) alone. Companies that embrace the culture of people oriented culture will conduct the role and function of human resources and will be encouraged to do human resource disclosure through Human Resource Disclosure on the company's annual report. It also explains that companies with people-oriented culture have belief values in vision and mission that emphasize the importance of human resources. In addition, belief values in the company will also affect the way to think and behave in the company in order to maintain a relationship with the stakeholders. Therefore, companies with a culture of organizations that are increasingly people oriented culture will perform the greater Human Resource Disclosure as proof of the action of corporate human resources management to all stakeholders.

The results of this study confirm that institutional ownership has no effect on Human Resource Disclosure [17]. Companies with a high level of institutional ownership do not guarantee that the company will conduct Human Resource Disclosure. Institutional investors who have a stake in the company are ineffective in supervising and monitoring the management policies and delegating those supervisory functions to the company's Board of Commissioners. One of the company's management policies is to provide additional information about Human Resource Disclosure in the company's annual report as a form of accountability to the stakeholders. In addition, institutional investors are also unaware that human resource-related disclosures are important and focus more on improving the company's financial performance.

In an organization there is a "tone at the top" which is a form of statement, expression, attitude, as well as the will of the top leader who put pressure to encourage all subordinates in the organization to move to a common goal. Therefore, the role of the company's top leaders, including the Board of Commissioners and institutional investors, is crucial to encourage management to do Human Resource Disclosure. When the top leader does not feel that Human Resource Disclosure is important to do by the company, the management will not be encouraged to do Human Resource Disclosure. Institutional investors in the company also consider the cost and benefits acquired by the company when providing additional information in the annual report of Human Resource Disclosure. By doing Human Resource Disclosure as an additional form of information in the annual report, it will give rise to cost or additional costs incurred by the company. Therefore, institutional investors will be more interested in increasing profitability in the company's financial performance. Therefore, the large share ownership of the institutions of the company will not affect the breadth of Human Resource Disclosure by the company

The results of this research confirm that the independent Commissioner has no effect on Human Resource Disclosure [3]. Companies with large numbers of independent commissioners do not warrant that the company will conduct Human Resource Disclosure. The existence of independent commissioners who are neutral and independent parties and do not have a relationship and special relationship to the company is not able to affect the company in providing additional information of Human Resource Disclosure. The participation of independent Commissioners in the function of alignment of various interests including company interests and stakeholder interests has not been effective. It is because the independent commissioner has limitations in the management of the company and does not guarantee that all independent Commissioners can perform its functions properly. The existence of independent commissioners in the company is often only a formality and elected by the company by title or relation to meet regulatory needs [17]. The existence of independent commissioners in the company measured by the 
proportion of independent Commissioners with the total Commissioner can not affect the small Human Resource Disclosure. This is because the terms of quality is the completeness of disclosure made by the company as a form of accountability to the stakeholders is more determined on the competence and ability of independent Commissioners in realizing the importance of Human Resource Disclosure and not solely based on the number of independent commissioners in the company. Therefore, the large number of independent commissioners in a company has no effect on the extensive Human Resource Disclosure conducted by the company

\section{CONCLUSION}

The results of this study showed that organizational culture positively affects Human Resource Disclosure. This is because companies with people-oriented culture will focus on human resources in all activities that are done to achieve success and not only focus on tasks and responsibilities that must be done (task-oriented culture) alone. Companies that embrace the culture of people oriented culture will be able to conduct the role and function of human resources and will be encouraged to do human resource disclosure through Human Resource Disclosure on the company's annual report. Thus, companies that are increasingly people-oriented culture will be increasingly encouraged to conduct Human Ressource Disclosure.

Institutional ownership has no effect on Human Resource Disclosure. This is because institutional investors who have a stake in the company are ineffective in supervising and monitoring the management policies and delegating the supervisory function to the company's board of Commissioners. In addition, the institutions are not yet aware of the importance of human resources-related disclosures and more focused on improving the company's performance that will increase company value and maximize shareholder benefits. Thus, the large share of the institutional investors of the company will not affect the extensive Human Resource Disclosure by the company.

Independent commissioners have no effect on Human Resource Disclosure. The existence of independent commissioners in the company is often only a formality to meet regulatory needs so that the existence of independent commissioners in the company becomes ineffective in conducting monitoring function and not to use its independence well to supervise management policies or directors of the company. Therefore, the existence of independent Commissioners can not supervise the management policy in conducting Human
Resource Disclosure. Thus, it can be concluded that the small number of independent commissioners in a company does not affect the vast Human Resource Disclosure conducted by the company.

The company's size proved to be positively influential in Human Resource Disclosure. This reflects that the company with an increasingly larger size than the total assets owned by the company will be even greater Human Resource Disclosure. Large enterprises will be easier to obtain additional funds and will be encouraged to give full liability to all stakeholders through additional information in the annual report on Human Resource Disclosure.

The profitability measured by Return On Asset have no effect on Human Resource Disclosure. This reflects that profitability does not determine the breadth of disclosures made by the company. Companies with greater profit will be encouraged to focus on business development by expanding and diversifying products and services rather than doing Human Resource Disclosure.

This research has some limitations, namely first, this research only uses the annual report to obtain information on Human Resource Disclosure. Second, this study only uses a dummy variable measurement in the organization culture variable. Third, this research only uses measuring methods by comparing the proportion of shares owned by the institution to the total shares circulating. Fourth, for the institutional ownership variable, the research uses only measuring method by comparing the number of independent Commissioners with the sum of all the company's board of Commissioners in the variable independent commissioners. Fifth, this research only uses regulations that refer to the Financial Services Authority.

With the limitations in this study, further research can use other data such as press releases, websites or official websites of companies and media reports as additional information related to Human Resource Disclosure conducted by the company, use other measurements in organizational culture variables by adopting a more comprehensive measurement, use other measurements of the institutional ownership variables with the measures of board commissioners meeting, use other measurements on the variable of independent commissioners with a diversity board, and use the applicable accounting rules and standards that refer to the financial accounting standards statement.

\section{REFERENCES}

[1] Ahmad, A.C. and Jusoh, M.A. (2014). Institutional ownership and market based performance indicators. Procedia Social and Behavioral Sciences, 164, 477-485. 
[2] Alawi, N.A. (2018). Human resources disclosure: an exploratory study of the quality in Qatar. World Journal of Entrepreneurship, Management and Sustainable Development, 15(1), 84-95. https://doi.org/10.1108/wjemsd01-2018-0010.

[3] Bowrin, F. (2018). Human resources disclosures by african and carribean Journal of Applied Accounting Research, 11. https://doi. org/10.1108/jaar.2010.37511aaa.003.

[4] Chusnah, F.N., Zulfiati, L., and Supriati, D. (2014). Pengaruh intellectual capital terhadap kinerja perusahaan dengan strategi sebagai pemoderasi. Simposium Nasional Akuntansi (SNA) XVII: Mataram.

[5] David, F.R., dan David, F.R., Pendekatan Keunggulan bersaing, edisi 15, Salemba Empat., Jakarta, 2016.

[6] Effendi, M.A., The Power of Good Corporate Governance: Teori dan Implementasi, Salemba Empat., 2016.

[7] Islahuzaman. (2006). Akuntansi sumber daya manusia dan kendala penerapannya. Jurnal Bisnis, Manajemen, dan Ekonomi, 8(1).

[8] Jensen, M. C., dan W. H. Meckling. (1976). Theory of the firm: Managerial behavior, agency costs and ownership Structure. Journal of Financial Economics, 3(4), 305-360

[9] Kartikasari, Y.D. (2016). Pengaruh good corporate governance dan modal intelektual terhadap kinerja keuangan pada perusahaan sektor keuangan yang terdaftar di bursa efek indonesia tahun 2011-2015. (Skripsi, Program Studi Akuntansi Jurusan Pendidikan Akuntansi Fakultas Ekonomi Universitas Negeri Yogyakarta, Yogyakarta, Indonesia). Didapat dari http://journal.student.uny.ac.id/.

[10] Kaur, S., Raman, V.A., and Singhania, M. (2016). Impact of corporate characteristics on human resource disclosures. Asian Review of Accounting, 24(4), 390-425. https://doi.org/ 10.1108/ARA-09-2014-0103.

[11] Koesmono, T. (2005). Pengaruh budaya organisasi terhadap motivasi dan kepuasan kerja serta kinerja karyawan pada sub sektor industri pengolahan kayu skala menengah di Jawa Timur. Jurnal Manajemen Dan Wirausaha, 7(2), 171-188. https://doi.org/10.9744/ jmk.7.2.pp.171-188.

[12] Kreitner, R, and A. Kinicki., Organizatinal Behaviour, Fifth Edition, Mc Graw Hill., Jakarta, 2005.

[13] Lukviarman, Corporate Governance. Solo: PT. Era Adicitra Intermedia, 2016.

[14] Mayo. (2000). The role of employee development in the growth of intellectual capital. Personal Review, 29(4). http://www.emeraldlibrary.com.
[15] Mishra, L., and Mishra, R. (2017). Human resource disclosure and it's association with corporate Attributes. Global Journal of Management and Business Research, 17(5), 9-20.

[16] Mukhtaruddin, Relasari, dan Felmania. (2014). Good corporate governance mechanism, corporate social responsibility disclosure on firm value: empirical study on listed company in Indonesia Stock Exchange". International Journal of Finance dan Accounting Studies, 2 (1)

[17] Ojokuku, R.M., and Oladejo, K.S. (2017). Firms characteristics and human resource disclosure in Nigerian Quoted Manufacturing Companies. International Journal of Finance and Management in Practice, 5(1), 10-22.

[18] Petera, P., and Wagner, J. (2017). Human resources disclosure among companies in Czechia. Social Responsibility Journal, 13(4), 743-761. https://doi.org/10.1108/SRJ-07-20170123

[19] Purnama, J.B. (2016). Optimalisasi sumber daya manusia. Jurnal Manajemen Pendidikan, 12(6).

[20] Roos, Johan., Goran Roos, Nocola C. Dragonetti, and Leif Edvinsson, Intellectual Capital Navigating the New Business Landscape, MacMillan Press Ltd., London, 1997.

[21] Sawarjuwono, T., dan A. P. Kadir. (2003). Intellectual capital: perlakuan, pengukuran dan pelaporan. Jurnal Akuntansi dan Keuangan, 5(1), 35-57.

[22] Shaw, John. C., Corporate Governance and Risk: A System Approach, John Wiley and Sons, Inc., New Jersey, 2003.

[23] Solechan, A. (2017). Pengaruh efisiensi modal intelektual terhadap kinerja keuangan perusahaan di Indonesia. Jurnal Kajian Akuntansi, 1(1), 83-96.

[24] Tahir, S. H., Saleem, M., and Arshad, H. (2015). Institutional ownership and corporate value. Praktični Menadžment, 6(1), 41-49.

[25] Wen, Y. and Jia, J.Y. (2010). Institutional ownership and managerial ownership in Bank Holding Companies. International Review of Accounting, Banking and Finance, 2(1), 9-22.

[26] Widodo, N.M. (2014). Pengaruh karakteristik perusahaan terhadap pengungkapan akuntansi sumber daya manusia. Simposium Nasional Akuntansi XVII: Lombok.

[27] Yulianto and Pratiwi. (2016). Pengaruh struktur kepemilikan dan dewan komisaris independen terhadap biaya keagenan perusahaan yang masuk dalam Indonesia Most Trusted Companies. Management Analysis Journal, $5(3)$. 